\title{
Vitamin B supplementation for diabetic peripheral neuropathy
}

Bhavani Jayabalan ${ }^{1}$, MBBS, MMed, Lian Leng $\underline{\text { Low }}^{2}$, MBBS, MMed

\begin{abstract}
Vitamin $B_{12}$ deficiency has been associated with significant neurological pathology, especially peripheral neuropathy. This review aims to examine the existing evidence on the effectiveness of vitamin $B_{12}$ supplementation for the treatment of diabetic peripheral neuropathy. A search of PubMed and the Cochrane Central Register of Controlled Trials for all relevant randomised controlled trials was conducted in December 2014. Any type of therapy using vitamin $B_{12}$ or its coenzyme forms was assessed for efficacy and safety in diabetics with peripheral neuropathy. Changes in vibration perception thresholds, neuropathic symptoms and nerve conduction velocities, as well as the adverse effects of vitamin $B_{12}$ therapy, were assessed. Four studies comprising 363 patients met the inclusion criteria. This review found no evidence that the use of oral vitamin $B_{12}$ supplements is associated with improvement in the clinical symptoms of diabetic neuropathy. Furthermore, the majority of studies reported no improvement in the electrophysiological markers of nerve conduction.
\end{abstract}

Keywords: cobalamin, diabetic neuropathy, vitamin $B_{12}$

\section{INTRODUCTION}

Diabetic peripheral neuropathy (DPN) affects approximately $44 \%$ of older diabetics. ${ }^{(1,2)}$ Some DPN patients may experience extremely painful symptoms, whereas those who have a more marked neuropathic deficit may not have any symptoms. Chronic sensorimotor neuropathy is characterised by pain, paraesthesia and sensory loss. Several pathogenic mechanisms contribute to the DPN aetiology, including microangiopathy and oxidative stress. Current clinical management guidelines for DPN are limited to adequate glucose control and symptomatic pain relief.

Deficiency of vitamin $B_{12}$ (also known as cobalamin), which results in a lack of methylcobalamin, has been associated with significant neurological pathology, especially peripheral neuropathy. ${ }^{(3,4)}$ It is also associated with the onset of diabetic neuropathy. In patients with DPN, vitamin $B_{12}$ deficiency may be caused by the use of antidiabetic agents such as metformin. ${ }^{(5,6)}$

For many years, vitamin $\mathrm{B}_{12}$ and its coenzymes have been used to treat pain. In some countries, vitamin $B_{12}$ is categorised as an analgesic drug. It has been suggested that vitamin $B_{12}$ may increase the availability and effectiveness of noradrenaline and 5 -hydroxytryptamine in the descending inhibitory nociceptive system. ${ }^{(7)}$ In animal models, morphological and histological evidence has also shown that long-term administration of methylcobalamin promotes the synthesis and regeneration of myelin. ${ }^{(8)}$

In June 2005, Sun et al conducted a systematic review on the effectiveness of vitamin $\mathrm{B}_{12}$ on diabetic neuropathy. ${ }^{(9)}$ The review included seven randomised controlled trials (RCTs), but only two RCTs were of good quality and had a Jadad score of 3 out of 5 . Sun et al concluded that, among patients with diabetic neuropathy, treatment with both combination agents and pure methylcobalamin appeared to improve the symptoms rather than electrophysiologic results. ${ }^{(9)}$ Other goodquality studies have been published since 2006, warranting an updated review on this topic. This article aimed to review the effectiveness of vitamin $B_{12}$ supplementation, in isolation or as a combination therapy, for the treatment of DPN. The most important outcome measure was symptom relief, followed by objective measures such as vibration perception threshold (VPT) and nerve conduction.

\section{METHODS}

PubMed and the Cochrane Central Register of Controlled Trials (CENTRAL) were searched to identify suitable clinical trials published from 1 January 1990 to 30 December 2014. The literature search strategy used was "(diabetic neuropathy) AND (vitamin $B_{12}$ OR cyanocobalamin OR methylcobalamin)". Selection of studies, data extraction and assessment of methodological quality were performed independently and duplicated by two reviewers. The following inclusion criteria were used: (a) RCTs with diabetic subjects; (b) studies that assessed any type of therapy with vitamin $B_{12}$ and its coenzymes (i.e. methylcobalamin, cyanocobalamin), in either oral or injectable forms; (c) a follow-up period of at least three months; and (d) a Jadad score $\geq 3$. Observational studies, studies focusing on a specific population such as patients with uraemia, animal studies and non-English studies were excluded.

After filtering for the inclusion and exclusion criteria, the PubMed search yielded 13 potentially relevant articles. Of these 13 studies, three had objectives not relevant to this discussion (e.g. total homocysteine is associated with diabetic nephropathy), three did not include vitamin $B_{12}$ in the treatment regimen (e.g. vitamin $B_{6}$ supplementation) and three had Jadad scores of $0-1$. Ultimately, four RCTs from PubMed 


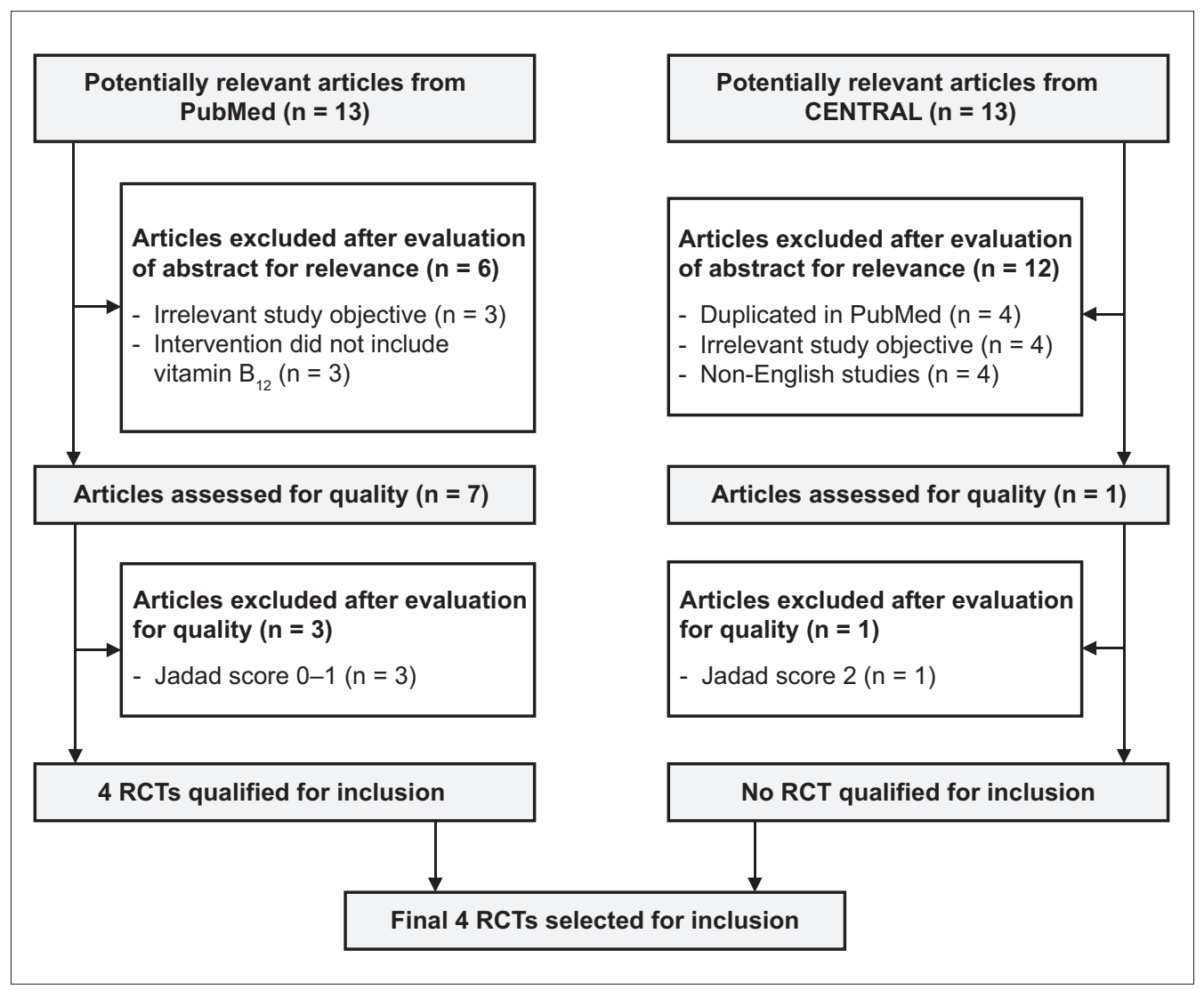

Fig. 1 Selection process of randomised controlled trials (RCTs) for inclusion in review.

were selected for review. The search performed on CENTRAL yielded 13 potentially relevant articles. Four were duplicated on the PubMed search, four were non-English studies and four had objectives not relevant to this review. Only one study was finally selected for review. However, on further assessment, the article was found to be of low quality, with a Jadad score of 2 . Consequently, four RCTs, ${ }^{(10-13)}$ comprising 363 patients, out of 26 potentially relevant articles found on PubMed and CENTRAL were reviewed. The selection process is shown in Fig. 1. The following information was extracted from the four selected RCTs: Jadad scores; characteristics of the study population; information on type, dosage, duration and method of administration of vitamin $B_{12}$ and the placebo/comparator; primary and secondary outcomes; results; and adverse effects. The extracted information is summarised in Tables I and II.

\section{RESULTS}

All the selected RCTs were randomised, double-blinded placebocontrolled trials. One of them had a Jadad score of $5,{ }^{(10)}$ two had a score of $4^{(11,12)}$ and one had a score of $3 .^{(13)}$ Two RCTs studied only patients with type 2 diabetes mellitus (DM), ${ }^{(10,11)}$ while the other two RCTs studied patients with either type 1 or type 2 DM. ${ }^{(12,13)}$ The age range of the study population was $25-80$ years. In two studies, ${ }^{(12,13)}$ DPN was defined as the presence of at least one subjective symptom and two out of three objective criteria of neuropathy. The symptoms were paraesthesia, a burning sensation, numbness, loss of sensation and muscle cramps. The clinical signs were absence of ankle jerks and/or other tendon reflexes, impairment of vibration sense, decreased sensation to pain and/or lower motor neuron weakness. In Farvid et al's study, neuropathy was measured using the Michigan Neuropathy Screening Instrument (MNSI), a brief 15-item questionnaire. ${ }^{(10)}$ In Fonseca et al's study, neuropathy was assessed objectively as those with a VPT of 25-45 volts at the hallux of either leg. ${ }^{(11)}$ Serum $\mathrm{B}_{12} /$ methylmalonic acid/homocysteine levels were measured at baseline in Fonseca et al's study; the mean levels were found to be normal and similar between the intervention and control groups. ${ }^{(11)}$ Only the baseline serum $B_{12}$ levels, which were comparable between the treatment and placebo groups, were reported in Farvid et al's study. ${ }^{(10)}$ Stracke et al excluded patients with vitamin $B_{12}$ deficiency from their study. ${ }^{(13)}$

Vitamin $B_{12}$ occurs in several forms known as cobalamins. Cyanocobalamin is the principal form used in vitamin supplements, while methylcobalamin is a coenzyme form that acts as an important co-factor in the activities of vitamin $B_{12}$-dependent methyltransferases. ${ }^{(14)}$ All four studies used primarily vitamin $B_{12}$ in its oral form. Oral methylcobalamin was used as a monotherapy in one study, ${ }^{(12)}$ while the remaining three studies used vitamin $B_{12}$ in combination with other vitamins. ${ }^{(10,11,13)}$ The dosage of vitamin $B_{12}$ (i.e. cyanocobalamin) ranged from 20 mcg to 1,840 mcg daily. ${ }^{(10,13)}$ Methylcobalamin dosage was between $4 \mathrm{mg}$ and 1,500 mg daily. ${ }^{(11,12)}$ The duration of therapy in the four studies varied from 12 weeks $^{(13)}$ to 16 weeks $^{(10,12)}$ and 24 weeks. $^{(11)}$

In Fonseca et al's study, compliance to therapy was checked through the measurement of changes in the serum level of 
Table I. Characteristics of the included randomised controlled trials (RCTs). ${ }^{(10-13)}$

\begin{tabular}{|c|c|c|c|c|c|c|c|}
\hline $\begin{array}{l}\mathrm{RCT}, \\
\text { year }\end{array}$ & $\begin{array}{l}\text { Jadad } \\
\text { score }\end{array}$ & $\begin{array}{l}\text { Study } \\
\text { population }\end{array}$ & $\begin{array}{l}\text { Sample size/ } \\
\text { demographics }\end{array}$ & Dropout & $\begin{array}{l}\text { Type of vitamin B/placebo; } \\
\text { form of administration }\end{array}$ & $\begin{array}{l}\text { Duration/dose } \\
\text { of treatment }\end{array}$ & Outcome of interest \\
\hline $\begin{array}{l}\text { Fonseca } \\
\text { et al, } \\
2013^{(11)}\end{array}$ & 4 & $\begin{array}{l}\text { Patients with } \\
\text { type } 2 \text { DM and } \\
\text { neuropathy }\end{array}$ & $\begin{array}{l}\mathrm{n}=214 ; \\
148 \text { male, } \\
66 \text { female; } \\
25-80 \mathrm{yr}\end{array}$ & $\begin{array}{l}14 \text { each from } \\
\text { intervention } \\
\text { and control } \\
\text { group }\end{array}$ & $\begin{array}{l}\text { Intervention: Metanx } \\
\text { (L-methylfolate calcium } \\
3 \mathrm{mg} \text {, methylcobalamin } \\
2 \mathrm{mg} \text { and pyridoxal } \\
\text { 5'-phosphate } 35 \mathrm{mg} \text { ) } \\
\text { Control: Placebo }\end{array}$ & $\begin{array}{l}\text { Duration: } 24 \text { wk } \\
\text { Dose: } 1 \text { tablet, } \\
\text { twice daily }\end{array}$ & $\begin{array}{l}\text { Primary: VPT } \\
\text { Secondary: Neuropathic } \\
\text { symptoms as measured } \\
\text { by the NTSS- } 6 \text { and NDS }\end{array}$ \\
\hline $\begin{array}{l}\text { Farvid } \\
\text { et al, } \\
2011^{(10)}\end{array}$ & 5 & $\begin{array}{l}\text { Patients with } \\
\text { type } 2 \text { DM }\end{array}$ & $\begin{array}{l}n=75 \\
39 \text { male, } \\
36 \text { female; } \\
36-69 \text { yr }\end{array}$ & $\begin{array}{l}\text { Vitamin B } \\
\text { group }(n=3) \\
\text { Non-vitamin B } \\
\text { group }(n=2) \\
\text { Placebo } \\
\text { group }(n=3)\end{array}$ & $\begin{array}{l}\text { Vitamin B intervention: } \\
\mathrm{Mg}, \mathrm{Zn} \text {, vitamin } \mathrm{C}, \\
\text { vitamin } \mathrm{E} \text {, vitamin } \mathrm{B}_{1}, \mathrm{~B}_{2}, \mathrm{~B}_{6} \text {, } \\
\mathrm{B}_{12} \text { (cyanocobalamin) } \\
10 \mu \mathrm{g}, \text { biotin and folic acid } \\
\text { Non-vitamin B intervention: } \\
\mathrm{Mg}, \mathrm{Zn} \text {, vitamin } \mathrm{C} \text {, vitamin } \mathrm{E} \\
\text { Control: Placebo }\end{array}$ & $\begin{array}{l}\text { Duration: } 16 \text { wk } \\
\text { Dose: } 2 \text { capsules } \\
\text { daily }\end{array}$ & $\begin{array}{l}\text { Primary: Neuropathic } \\
\text { symptoms based on } \\
\text { MNSI questionnaire and } \\
\text { examination } \\
\text { Secondary: Nerve } \\
\text { conduction velocities }\end{array}$ \\
\hline $\begin{array}{l}\text { Stracke } \\
\text { et al, } \\
1996^{(13)}\end{array}$ & 3 & $\begin{array}{l}\text { Patients with } \\
\text { insulin-dependent } \\
\text { type } 1 \text { or } 2 \text { DM } \\
\text { with overt } \\
\text { diabetic } \\
\text { polyneuropathy } \\
\text { of at least } 4 \text { mth }\end{array}$ & $\begin{array}{l}n=24 ; \\
14 \text { male, } \\
10 \text { female; } \\
40-60 y r\end{array}$ & $\begin{array}{l}2 \text { from } \\
\text { intervention } \\
\text { group }\end{array}$ & $\begin{array}{l}\text { Intervention: Milgamma } \\
\text { capsules (benfotiamine } \\
40 \mathrm{mg} \text {, pyridoxine } \\
\text { hydrochloride-vitamin } \mathrm{B}_{6} \\
90 \mathrm{mg} \text { and cyanocobalamin } \\
0.23 \mathrm{mg} \text { ) } \\
\text { Control: Placebo }\end{array}$ & $\begin{array}{l}\text { Duration: } 12 \text { wk } \\
\text { Dose: } 2 \text { capsules, } \\
4 \text { times daily for } \\
2 \text { wk followed by } \\
1 \text { capsule, } \\
3 \text { times daily for } \\
10 \text { wk }\end{array}$ & $\begin{array}{l}\text { Primary: VPT and nerve } \\
\text { conduction velocity } \\
\text { Secondary: Biochemical } \\
\text { markers }\end{array}$ \\
\hline $\begin{array}{l}\text { Yaqub } \\
\text { et al, } \\
1992^{(12)}\end{array}$ & 4 & $\begin{array}{l}\text { Patients } \\
\text { with diabetic } \\
\text { neuropathy }\end{array}$ & $\begin{array}{l}n=50 ; \\
25 \text { male, } \\
23 \text { female; } \\
40-60 y r\end{array}$ & $\begin{array}{l}\text { Intervention } \\
\text { group }(n=4) \\
\text { Placebo } \\
\text { group }(n=3)\end{array}$ & $\begin{array}{l}\text { Intervention: } \\
\text { Methylcobalamin capsules } \\
250 \text { mg } \\
\text { Control: Placebo }\end{array}$ & $\begin{array}{l}\text { Duration: } 16 \text { wk } \\
\text { Dose: } 2 \text { capsules, } \\
3 \text { times daily }\end{array}$ & $\begin{array}{l}\text { Primary: PNS (includes } \\
\text { somatic symptoms, } \\
\text { autonomic symptoms } \\
\text { and clinical signs) } \\
\text { Secondary: Nerve } \\
\text { conduction studies }\end{array}$ \\
\hline
\end{tabular}

DM: diabetes mellitus; Mg: magnesium; MNSI: Michigan Neuropathy Screening Instrument; NDS: Neuropathy Disability Score; NTSS-6: 6-item Neuropathy Total Symptoms Score; PNS: Peripheral Neurology Score; VPT: vibration perception threshold; Zn: zinc

vitamin $B_{12}$ as prescribed to the participants. ${ }^{(11)}$ Farvid et al supplemented this with capsule counts and individual sessions with skilled counsellors, who promoted compliance to the intervention at regular intervals. ${ }^{(10)}$ Two of the studies did not mention how compliance to therapy was ensured. ${ }^{(12,13)}$

The main outcomes in the selected RCTs can be grouped into electrophysiological measures (namely VPTs and/or nerve conduction velocities) and neuropathic symptoms. In two of the studies, nerve conduction velocities were evaluated using standard techniques, as described by Kimura, ${ }^{(15)}$ at room temperature. ${ }^{(10,12)}$ Farvid et al's study measured neuropathy symptoms using the MNSI questionnaire, which generated total scores before and after intervention. ${ }^{(10)}$ In Yaqub et al's study, individual components of the Peripheral Neurology Symptom (PNS) score were used to assess somatic symptoms, autonomic symptoms and clinical signs. ${ }^{(12)}$ In Fonseca et al's study, symptoms and disability were assessed using the 6-item Neuropathy Total Symptom Score (NTSS-6) and the Neuropathy Disability Score, respectively. ${ }^{(11)}$

All the studies analysed outcomes relating to VPTs or nerve conduction velocities. Two of the four studies ${ }^{(10,12)}$ showed no significant clinical improvement of nerve conduction velocities in the intervention groups as compared to the placebo groups. Similarly, another study demonstrated no difference in the VPT between the treatment and placebo groups. ${ }^{(11)}$ Only one study demonstrated statistically significant $(p=0.006)$ improvement in the nerve conduction velocity of the peroneal nerve by $1.1 \mathrm{~m} / \mathrm{s}$ compared to that of the placebo group, which dropped by $2.7 \mathrm{~m} / \mathrm{s}^{\left({ }^{(13)}\right.}$ This same study also showed a statistically upward trend in the VPT, approaching a mean of $1.4 \mu \mathrm{m}$ at week 12 of treatment compared to $2.0 \mu \mathrm{m}$ at baseline. ${ }^{(13)}$

Of the three studies that looked at neuropathic symptoms as a primary outcome measure, only one showed improvement in this aspect. Fonseca et $\mathrm{al}^{(11)}$ reported a significant improvement in NTSS- 6 scores in the group receiving Metanx ${ }^{\circledR}$ (containing L-methylfolate calcium $3 \mathrm{mg}$, methylcobalamin $2 \mathrm{mg}$ and pyridoxal 5'-phosphate $35 \mathrm{mg}$ ) as compared to the placebo group at week 24 of intervention $(-0.96 \pm 1.54$ vs. $-0.53 \pm 1.69$; $p=0.033)$, but did not specify its clinical significance. Yaqub et al's study, ${ }^{(12)}$ which looked at the individual components of the PNS score, showed a significant improvement in somatic $(p=0.003)$ and autonomic $(p=0.01)$ symptoms in patients receiving methylcobalamin; however, the authors did not compare the improvements with the placebo group. Farvid et al's study, ${ }^{(10)}$ which used the MNSI score to assess neuropathic symptoms, showed an improvement in both the treatment (i.e. vitamin B and non-vitamin B supplementation) and placebo groups after four months, although no significant differences between the three groups were observed.

No adverse events were observed in two studies. ${ }^{(12,13)}$ Fonseca et al reported one case of rash in the intervention group, which was possibly related to the study intervention; however, no patient withdrew from the study due to adverse events. ${ }^{(11)}$ Farvid et al did not report any data relating to adverse events. ${ }^{(10)}$ 
Table II. Summary of results of the included randomised controlled trials (RCTs). ${ }^{(10-13)}$

\begin{tabular}{|c|c|c|c|c|}
\hline $\mathrm{RCT}$, year & VPT & Neuropathic symptoms & Nerve conduction velocities & Adverse effects \\
\hline $\begin{array}{l}\text { Fonseca } \\
\text { et al, } \\
2013^{(11)}\end{array}$ & $\begin{array}{l}\text { Mean baseline VPT: } \\
32.16 \pm 13.00 \mathrm{~V} \text { to } \\
33.88 \pm 14.24 \mathrm{~V} \\
\text { Wk 24: } \\
\text { Metanx: } 1.96 \pm 13.08 \mathrm{~V} \\
\text { Placebo: } 3.27 \pm 10.32 \mathrm{~V} \\
\text { Not statistically } \\
\text { significant }\end{array}$ & $\begin{array}{l}\text { Mean Baseline NTSS-6 (range 0-21.96) } \\
3.45 \pm 2.05 \text { to } 3.73 \pm 1.79 \\
\text { Wk 16: Metanx: }-0.90 \pm 1.42 \\
\text { Placebo: }-0.40 \pm 1.72 \\
(p=0.013) \\
\text { Wk 24: Metanx: }-0.96 \pm 1.54 \\
\text { Placebo: }-0.53 \pm 1.69(p=0.033) \\
\text { Statistically significant symptomatic } \\
\text { improvement } \\
\text { NDS score } \\
\text { Wk 16: Metanx: }-0.78 \pm 2.13 \\
\text { Placebo: }-0.18 \pm 2.24(p=0.027) \\
\text { Wk 24: Metanx: }-0.47 \pm 2.11 \\
\text { Placebo: }-0.36 \pm 2.14 \\
\text { Not statistically significant }\end{array}$ & - & $\begin{array}{l}\text { Combined total } \\
\text { rate of adverse } \\
\text { events } 2 \% \text {; no } \\
\text { withdrawal due } \\
\text { to adverse events }\end{array}$ \\
\hline $\begin{array}{l}\text { Farvid } \\
\text { et al, } \\
2011^{(10)}\end{array}$ & - & $\begin{array}{l}\text { Changes in MNSI scores } \\
\text { Wk 16: } \\
\text { Vitamin B group: } 3.45 \rightarrow 0.64(p=0.001) \\
\text { Non-vitamin B group: } \\
3.96 \rightarrow 1.00(p=0.001) \\
\text { Placebo: } 2.54 \rightarrow 1.95(p=0.001) \\
\text { Improvement in MNSI scores in both } \\
\text { groups; no significant differences } \\
\text { between groups }\end{array}$ & $\begin{array}{l}\text { No statistically significant changes } \\
\text { in median, ulnar, peroneal, tibial } \\
\text { and sural nerve conduction } \\
\text { velocities in intervention groups }\end{array}$ & Not mentioned \\
\hline $\begin{array}{l}\text { Stracke } \\
\text { et al, } \\
1996^{(13)}\end{array}$ & $\begin{array}{l}\text { Metacarpal II } \\
\text { Wk } 0 \text { to wk 12: } \\
\text { Milgamma: } 2.0(1.3- \\
3.3) \mathrm{V} \rightarrow 1.4(1.2-1.7) \mathrm{V} \\
\text { Placebo: } 1.8(1.2-2.6) \\
\mathrm{V} \rightarrow 1.9(1.4-2.5) \mathrm{V} \\
(p=0.168) \\
\text { Reduction in VPT } \\
\text { but not statistically } \\
\text { significant }\end{array}$ & - & $\begin{array}{l}\text { Peroneal nerve } \\
\text { Wk } 0 \text { to wk 12: } \\
\text { Milgamma: } 40.2(36.5-44.0) \mathrm{m} / \mathrm{s} \rightarrow \\
41.3(37.5-45.1) \mathrm{m} / \mathrm{s} \\
\text { Placebo: } 43.1(38.3-48.0) \mathrm{m} / \mathrm{s} \rightarrow \\
40.4(37.6-43.1) \mathrm{m} / \mathrm{s} \\
(p=0.006) \\
\text { Nerve conduction velocity } \\
\text { improved in the peroneal nerve but } \\
\text { not in the median nerve }\end{array}$ & $\begin{array}{l}\text { No side effects } \\
\text { observed }\end{array}$ \\
\hline $\begin{array}{l}\text { Yaqub } \\
\text { et al, } \\
1992^{(12)}\end{array}$ & - & $\begin{array}{l}\text { PNS somatic symptoms component } \\
\text { (range } \mathbf{0 - 1 4 0 )} \\
\text { Wk } 0 \text { to wk 16: } \\
\text { Methylcobalamin: } 72.2 \pm 32.2 \rightarrow 106.6 \pm 20.4 \\
\text { ( } p=0.003 \text { ) } \\
\text { Improvement in somatic symptoms, } \\
\text { autonomic symptoms and sensory signs } \\
\text { in methylcobalamin group after } 4 \text { mth; } \\
\text { no comparisons made with placebo }\end{array}$ & $\begin{array}{l}\text { Sensory NCS (max total score } 16 \text { ) } \\
\text { Wk } 0 \text { to wk 16: } \\
\text { Active: } 5.7 \pm 3.3 \rightarrow 7.3 \pm 4.1 \\
(p=0.09) \\
\text { Placebo: } 7.6 \pm 5.2 \rightarrow 7.7 \pm 4.0 \\
\text { Not statistically significant } \\
\text { No changes in motor group; } \\
\text { changes in sensory group not } \\
\text { statistically significant }\end{array}$ & $\begin{array}{l}\text { No side effects } \\
\text { observed }\end{array}$ \\
\hline
\end{tabular}

MNSI: Michigan Neuropathy Screening Instrument; NCS: nerve conduction studies; NDS: Neuropathy Disability Score; NTSS-6: 6-item Neuropathy Total Symptom Score; PNS: Peripheral Neurology Score; VPT: vibration perception threshold

\section{DISCUSSION}

Currently, the agents used to reduce symptoms of pain in DPN include anticonvulsants, tricyclic antidepressants and opioid or opioid-like analgesics. Unfortunately, there is no evidence that any of these agents modify the underlying pathophysiology of peripheral neuropathy. ${ }^{(16)}$ Studies have shown that high doses of methylcobalamin improved nerve conduction in streptozotocin-diabetic rats. ${ }^{(17)}$ This was again demonstrated in experimental acrylamide neuropathy, where high doses of methylcobalamin were associated with a significant increase in the rate of motor nerve fibre regeneration. ${ }^{(18)}$ This may be the mechanism through which methylcobalamin acts to modify and treat the underlying pathophysiology of peripheral neuropathy.
This review did not provide conclusive evidence that methylcobalamin, either in isolation or as a combination therapy, improves the clinical symptoms of DPN. The clinical significance of a one-point change in NTSS-6 score among patients with moderate or severe symptoms in the Metanx group is unclear. ${ }^{(11)}$ Although Yaqub et al's study showed symptom improvement in the methylcobalamin group, the results were not compared with the placebo group. ${ }^{(12)}$ Furthermore, Farvid et al's study showed no difference in the improvement of symptoms between the vitamin B and non-vitamin B groups; the study could have been underpowered and, thus, unable to detect a significant difference. ${ }^{(10)}$ Larger adequately powered trials are required before definite conclusions can be made regarding the effectiveness of vitamin B in relieving neuropathy symptoms. 
A majority of the studies did not find any improvement in the nerve conduction velocities or VPTs of patients suffering from DPN. Only Stracke et al ${ }^{(13)}$ showed a clinically significant improvement in one out of the two nerves studied. A postulated reason for this was that neurophysiological changes may need a longer time to become apparent.

Several limitations should be considered when interpreting the findings of this review. First, only two out of the four studies considered vitamin $\mathrm{B}_{12}$, methylmalonic acid and homocysteine levels as possible confounders for the response to vitamin $B_{12}$ therapy. ${ }^{(10,11)}$ Vitamin $B_{12}$ deficiency is known to cause peripheral neuropathy and is a risk factor for development of DPN in diabetics who are on metformin. The extent to which vitamin $B_{12}$ deficiency contributes to the symptoms of these patients is not clearly illustrated in the studies, although the patients' mean baseline vitamin $B_{12}$ levels were within normal range in two studies. ${ }^{(10,11)}$ Furthermore, as no serious adverse events were reported in most of the studies, no extended follow-up of patients to assess for harm due to supplementation was conducted. Finally, we searched only two databases for relevant articles and excluded all non-English studies.

\section{CONCLUSION}

This review suggests that pure methylcobalamin and combination vitamin $B_{12}$ therapy are unlikely to be potential candidates for the treatment of DPN symptoms. Although vitamin B therapy is generally safe and has minimal adverse effects, the evidence does not demonstrate a clear benefit in diabetics with peripheral neuropathy, in terms of reduction of symptoms and improvement in electrophysiological measures.

\section{REFERENCES}

1. Dyck PJ, Katz KM, Karnes JL, et al. The prevalence by staged severity of various types of diabetic neuropathy, retinopathy, and nephropathy in a population based cohort: the Rochester Diabetic Neuropathy Study. Neurology 1993; 43:817-24.

2. Kumar S, Ashe HC, Parnell LN, et al. The prevalence of foot ulceration and its correlates in type 2 diabetic patients: a population-based study. Diabet Med 1994; 11:480-4.

3. Head KA. Peripheral neuropathy: pathogenic mechanisms and alternative therapies. Altern Med Rev 2006; 11:294-329.

4. Andrès $\mathrm{E}$, Loukili NH, Noel $\mathrm{E}$, et al. Vitamin B12 (cobalamin) deficiency in elderly patients. CMAJ 2004; 171:251-9.

5. Liu KW, Dai LK, Jean W. Metformin-related vitamin B12 deficiency. Age Ageing 2006; 35:200-1.

6. Ting RZ, Szeto CC, Chan MH, Ma KK, Chow KM. Risk factors of vitamin $\mathrm{B}(12)$ deficiency in patients receiving metformin. Arch Intern Med 2006; 166:1975-9.

7. Jurna I. [Analgesic and analgesia-potentiating action of B vitamins]. Schmerz 1998; 12:136-41. German.

8. Okada K, Tanaka H, Temporin K, et al. Methylcobalamin increases Erk1/2 and Akt activities through the methylation cycle and promotes nerve regeneration in a rat sciatic nerve injury model. Exp Neurol 2010; 222:191-203.

9. Sun Y, Lai MS, Lu CJ. Effectiveness of vitamin B12 on diabetic neuropathy: systematic review of clinical controlled trials. Acta Neurol Taiwan 2005; 14:48-54.

10. Farvid MS, Homayouni F, Amiri Z, Adelmanesh F. Improving neuropathy scores in type 2 diabetic patients using micronutrients supplementation. Diabetes Res Clin Pract 2011; 93:86-94.

11. Fonseca VA, Lavery LA, Thethi TK, et al. Metanx in type 2 diabetes with peripheral neuropathy: a randomized trial. Am J Med 2013; 126:141-9.

12. Yaqub BA, Siddique A, Sulimani R. Effects of methylcobalamin on diabetic neuropathy. Clin Neurol Neurosurg 1992; 94:105-11.

13. Stracke H, Lindemann A, Federlin K. A benfotiamine-vitamin B combination in treatment of diabetic polyneuropathy. Exp Clin Endocrinol Diabetes 1996; 104:311-6.

14. Zhang YF, Ning G. Mecobalamin. Expert Opin Investig Drugs 2008; 17:953-64.

15. Kimura J. Electrodiagnosis in diseases of nerve and muscle: Principles and Practice. 3rd ed. Oxford University Press Inc, 2001:91-117.

16. Jacobs AM, Cheng D. Management of diabetic small-fiber neuropathy with combination L-methylfolate, methylcobalamin, and pyridoxal 5'-phosphate. Rev Neurol Dis 2011; 8:39-47.

17. Sonobe M, Yasuda H, Hatanaka I, et al. Methylcobalamin improves nerve conduction in streptozotocin-diabetic rats without affecting sorbitol and myo-inositol contents of sciatic nerve. Horm Metab Res 1988; 20:717-8.

18. Watanabe T, Kaji R, Oka N, Bara W, Kimura J. Ultra-high dose methylcobalamin promotes nerve regeneration in experimental acrylamide neuropathy. J Neurol Sci 1994; 122:140-3. 